University of Nebraska - Lincoln

DigitalCommons@University of Nebraska - Lincoln

To Improve the Academy

Professional and Organizational Development

Network in Higher Education

1995

Improving Students' Critical Thinking Outcomes: An Process-

Learning Strategy in Eight Steps

S. Kay A. Thornhill

Melissa Wafer

Follow this and additional works at: https://digitalcommons.unl.edu/podimproveacad

Part of the Higher Education Administration Commons

Thornhill, S. Kay A. and Wafer, Melissa, "Improving Students' Critical Thinking Outcomes: An ProcessLearning Strategy in Eight Steps" (1995). To Improve the Academy. 347.

https://digitalcommons.unl.edu/podimproveacad/347

This Article is brought to you for free and open access by the Professional and Organizational Development Network in Higher Education at DigitalCommons@University of Nebraska - Lincoln. It has been accepted for inclusion in To Improve the Academy by an authorized administrator of DigitalCommons@University of Nebraska - Lincoln. 


\section{Improving Students' Critical Thinking Outcomes: An Process-Learning Strategy in Eight Steps}

\section{S. Kay A. Thornhill}

Southeastern Louisiana University

\section{Melissa Wafer}

Our Lady of the Lake College

This article describes an eight-step strategy through which students learn to critically analyze situations that they have encountered in their clinical practice. The method was derived from Stephen Brookfield's four components of critical thinking and his suggestions for themes that relate to nursing culturalization. The approach used to develop this model has implications for educators in all fields because it illustrates a method for integrating the learning of critical thinking processes with their real-world applications.

Although educators in all disciplines share a general interest in developing students' ability to think critically, nurse educators are especially challenged because they must prepare their students to perform technical; interpersonal, and critical thinking skills simultaneously. They must learn to function as safe, competent, and skillful clinical nurse practitioners in a complex health care environment in which new information and new clinical situations continually emerge (del Bueno, 1990; Miller \& Malcolm,1990). 
In 1988, the U. S. Department of Education issued a mandate that required accrediting agencies to consider evidence of educational outcomes when conducting program reviews (U. S. Department of Education, 1988). As a result, nursing education's accrediting agency, the National League for Nursing (NLN), changed its accreditation criteria to include five required outcomes, including critical thinking, in Baccalaureate and Higher Degree Programs (National League for Nursing, 1991). As defined by the NLN, critical thinking should reflect student skills in reasoning, analysis, research, or decision making relevant to the discipline of nursing (National League for Nursing, 1992). In addition to these developments, the U.S. Department of Health and Human Services published a list of national health promotion and disease prevention objectives that supported the need to balance nursing education's program content and learning strategies (U.S. Department of Health and Human Services, 1992).

These factors provided the impetus for the authors' development of a process-focused critical thinking strategy. The authors' employment setting is a baccalaureate nursing program with over 500 nursing student majors, located in an urban area of the Southeastern region of the country. Students participating in the critical thinking activity selected acute cardiology nursing for their clinical learning setting in a nursing synthesis course. The cardiology nursing unit is located in a large urban regional medical center complex.

\section{Conceptual Framework}

In his 1987 book on developing critical thinkers, Stephen Brookfield posited four components of critical thinking: (1) identifying and challenging assumptions; (2) challenging the importance of context; (3) imagining and exploring alternatives; (4) reflective skepticism. More recently, Brookfield (1993) also suggested a "phenomenography of nurses as critical thinkers" to account for how nurses learn and experience critical thinking. Each of these culturalization themes has important implications for anyone who practices critical thinking in the field of nursing (and, potentially, many other professional fields): impostership, cultural suicide, lost innocence, roadrunning, and community. Because these themes are less widely known than Brookfield's 
components of critical thinking, they require some elaboration. A complete exploration of these themes is beyond the scope of this article, but brief definitions, based on Brookfield (1993), follows.

"Impostorship," common to many professionals, is a feeling of underlying incompetence that often does not diminish with years of practice. Imposters must always appear to know what they are doing and they live in fear that they will be "exposed" for the hopeless incompetents that really are. "Cultural suicide" refers to a kind of cultural alienation that can result when critically aware nurses question their colleagues who are less critically aware: ... nurses who expect their efforts to ignite a fire of enthusiasm for critical reflection and democratic experimentation may be sorely disappointed when they find themselves regarded as uncooperative subversives (and) whistleblowers ... (p. 201). The theme of "lost innocence" relates to the often sad discovery that there are no perfect, unchanging models of clinical practice, but only "the contextual ambiguity of practice" (p. 203). "Roadrunning" (inspired by the Warner Brothers cartoon) describes the state of limbo that occurs in the process of critical thinking when "we realize that the old ways of thinking and acting no longer make sense, but ... new ones have not yet formed to take their place" (p. 204). Brookfield explores this theme in the context of the rhythm and pace of the epistimologic, transformational process of critical thinking. "Community" is a more positive and hopeful theme that relates to the development of "emotionally sustaining peer groups" that may consist of just four or five good friends who "know that experiencing dissonance, challenging assumptions, taking new perspectives, and falling foul of conservative administrators are generic aspects of the critical process, not idiosyncratic events" (p. 205).

Brookfield's four components of critical thinking and his culturalization themes provided the conceptual framework for the authors' eight-step learning strategy for critical thinking. The process is initiated in Step One by the examination of a critical incident (a real-life situation) in nursing care. Steps Three, Four, Five, and Six incorporate Brookfield's four components of critical thinking, and his culturalization themes involve Steps Two and Seven. In Step Eight students explore the usefulness of critical incidents as a means of achieving their' learning outcomes. 


\section{The Eight-Step Process: Critical Thinking in Clinical Practice}

\section{Step One: Identify a Critical Incident}

In Step One students first identify critical incidents they encountered during clinical practice. As Brookfield (1993) advises, students are instructed to think about episodes in which they experienced "good" or "bad" forms of clinical practice. A critical incident cited by a student in the class is described below and used as an example in the remaining steps of the process:

The $\mathbf{4 0}$ year old cardiac patient was experiencing chest pain, nausea, vomiting, and headache. He was unable to take his oral medications for the heart condition and other problems. The student nurse notified the staff nurse assigned to the patient. The nurse told her not to "bother" the patient's physician because they had talked with him earlier and he was aware of the patient's present condition and had not given any additional orders to treat the patient. The nurse refused to call the physician for the student nurse.

\section{Step Two: Note Personal Experience}

In Step Two, the student describes why the incident should be defined as "critical." The student thinks about what happened during the incident and writes responses to four questions (Brookfield,1993): What triggered your engagement in critical thinking and was there a clear cause? As you moved through the situation, what resources were most helpful to you? What were the high and low points of the process? What happened because of the critical thinking process? The student's answers to these questions for the incident in Step One are given below:

An inability to relieve the patient of symptoms prompted the student to engage in critical thinking. The most helpful resource was the patient's understanding of the students desire to care him and the faculty serving as a resource when the staff nurse differed in the student's decision to call the physician. The helplessness experienced by the student nurse after the staff nurse refused to call the physician was the low point of the episode. 


\section{Step Three: Identify \& Challenge Assumptions}

In Step Three, the critical incidents provide the basis for exploring the values, beliefs, rationales, and appropriateness of ideas that influence their individual actions. Ideas are often based on cultural norms, ethnic values, influential teachers or mentors, or policies and procedures learned in discipline-specific programs, and these perspectives frame group discussions of each clinical practice incident. In the final exercise in Step Three, students identify assumptions and propose challenges on a group worksheet. In the incident in the example, students identified the following points:

1. Nurses rely on the medical doctor and or medications for relieving patient's symptoms.

2. Staff nurse showed more compassion and caring for the physician than for the patient.

3. Staff nurse feared physician actions more than patient as a consumer of health care.

4. Student nurse had more compassion and caring for the patient than did the primary nurse assigned to his care.

5. The patient was passive in his ability to treat himself and required the care of his admitting physician.

6. The staff nurse and student nurse were in conflict with the method of treatment.

\section{Step Four: Challenge the Importance of Context}

In Step Four, students examine the importance of the circumstances surrounding their critical incidents. Students must struggle with the difficulty of interpreting any action without considering the context within which the action occurred. This discussion includes an examination of the group worksheets from Step Three and how differing perspectives on the incidents help shape their interpretation.

Developmental context issues identified by the student nurse included the patient's loss of role functions: i.e. head of household, family provider, faced with serious debilitating heart disease at an early age. 
Professional context issues included student nurse-staff nurse relationships, student nurse-physician relationships. Students were concerned with care of this patient only and their perspective on the situation concerned only the patient, as opposed to staff nurses who were concerned with a myriad of other issues such as the physician's actions, the days unit staffing, and previous experiences in caring for the patient.

\section{Step Five: Imagine and Explore Alternatives}

Step Five is essentially a brainstorming session in which students explore alternatives to the way each critical incident occurred and speculate on ways to resolve each one. Students are encouraged to express their opinions about the outcomes of each situation. In the example, students suggested the following alternatives:

1. Student nurse could state she was caring for the patient also and would call the physician without the staff nurse's permission.

2. The student nurse could confer with a faculty member and request the faculty member call the physician.

3. The student nurse could present the situation to the nurse responsible for all patients care on the unit.

4. The student could explain to the patient the staff nurse's decision to not call the physician and perhaps the patient could call the physician from his room telephone.

5. The staff nurse could reassess the patient's chest pain and other symptoms, and call the physician to report the changes with additional orders to treat the patient's current status.

6. The student could reevaluate the situation from a more holistic viewpoint of the patient.

7. The student could provide nursing comfort measures for the symptoms noted for the patient without relying totally on the medical regimen.

\section{Step Six: Reflective Skepticism}

Following step five's brainstorming session, students begin to focus on possible outcomes of the critical incidents and to question the scenarios for their resolution. Students are urged to question ideas 
suggested as the answer for the critical incident as well as general assumptions about the explanation of human behavior. Students record these questions on their individual worksheets. Students generated the following questions in the example case:

1. Are the decisions made by the unit nurses regarding assigned patients made with an awareness that the decisions have an impact on all members of the health care team?

2. Are nurses a part of a collaborative effort to assure that quality care standards are maintained?

3. Are unit nurses accepting the accountability and responsibility for providing nursing care to all patients according to the hospitals established standards of care?

4. Is the patient allowed to participate in decisions related to his/her plan of care?

5. Are the patient's rights a factor in this situation?

\section{Step Seven: Consequences of Critical Thinking Experience}

Step Seven turns the focus of the discussion away from the critical thinking process itself and toward an exploration of the professional consequences that may result from their engagement in the critical thinking process. Using Brookfield's definitions of impostership, cultural suicide, lost innocence, roadrunning, and community, students discuss the implications of engaging in critical thinking in the specific context of their critical incidents. In their discussion of this theme, it becomes clear to students that there may be a variety of implications, some of which are very unpleasant, for practicing the critical thinking skills they have been working on in the course. In the example, students suggested the following consequences:

1. Calling the physician without the nurse's permission would be cultural suicide for the student. The student with less experience and nursing knowledge has questioned the nursing care practices of a "real" nurse.

2. Impostership may be a consequence also. The student nurse may agree with the staff nurse's decision to not call the physician but the "correct" decision is to be a patient advocate.

3. The situation is jolting to a student nurse who envisions nursing practice as nursing education has shaped the student's image of 
nursing practice. The student's way of interpreting nursing practice and the way nursing is practiced differs. This jolting, halting, and fluctuating rhythm is "roadrunning."

4. The student nurse realizes that nursing care practices and decisions involving patient care are complex and there are no set rules to serve as a rigid guide. Hence, another consequence may be "lost innocence."

\section{Step Eight: Impact of Thinking Critically on Learning Outcomes}

In the final step of the process, students identify concepts, themes, and issues that may have an impact on clinical practice and affect student learning outcomes. Students organize the critical incidents by focus areas, analyzing the impact of each area, and assess the impact of the learning activity on their learning outcomes. In this stage of the example case, students made these points:

1. Patient care decisions learned in education programs may differ in nursing practice since many variables are considered in actual nursing practice situations.

2. Nurses standards of care may differ from student nurses, from ones ascribed to, and from ones reflected in actual nursing practice.

3. Nurses practice nursing from a medical model of care more than from an interdisciplinary patient care framework.

\section{Conclusions and Recommendations}

Students were pleased with their critical thinking experience in this class, citing the use of real clinical situations as a basis for learning and how the process assisted them in clarifying course objectives, understanding the management theory of the course, and validating clinical outcome behaviors. The richness of the critical incidents they chose helped make the method a success. They explored situations relating to issues of management, patients and families, nurse-physician relationships, and clinical nursing practice. Students also participated freely in discussions and they differed widely in their individual responses during each step of the process. 
The eight-step critical thinking process encourages students to engage in critical thinking, to view situations from broad perspectives, and to seek solutions to problems and situations experienced in clinical practice settings. This learning strategy incorporates the realities of nursing practice, merges nursing education with practice, and involves students in affective, cognitive, and psychomotor domains of learning. It provides students with enhanced skills in critical thinking and prepares them to function in a dynamic and complex health care system. Baccalaureate nursing education programs seeking accreditation could document their graduates' critical thinking abilities using this strategy at all levels of the curriculum. Completing the eight-step critical thinking learning strategy could also serve as an alternative clinical learning method for Registered Nurse students and students absent from clinical practice.

Brookfield's culturalization themes for nursing and their relationship to critical thinking clearly have parallels in other professional fields. Educators in these fields might find it useful to study the extent to which the themes apply in other fields and possibly identify additional themes that could be used to teach the application and consequences of critical thinking in the real world. Critical incidents for use in the program could be suggested by recent graduates or developed by teachers, based on their own real-life experiences. Using Brookfield's model of the four components of critical thinking as a basis for analyizing these incidents, multi-step processes such as the one described in this article could be established in many other fields.

\section{References}

Allen, D., Bowers, B. \& Diekelmann, N. (1989). Writing to learn: A reconceptualization of thinking and writing in the nursing curriculum. Journal of Nursing Education, 28(1), 6-10.

Brookfield, S., (1987). Developing critical thinkers: Challenging adults to explore alternative ways of thinking and acting. San Francisco: Jossey-Bass Publishers.

Brookfield, S. (1993). On impostership, cultural suicide, and other dangers: How nurses learn critical thinking. Journal of Continuing Education in Nursing, 5(24), 197-205.

del Bueno, D.J. (1990). Experience, education, and nurses' ability to make clinical judgments. Nursing and Health Care, 11(6), 290-293.

Foster, P.J. Larson, D. \& Loveless, E.M. (1993). Helping students learn to make ethical decisions. Holistic Nursing Practice, 7(3), 28-35. 
Kramer, M. K. (1993). Concept clarification and critical thinking: Integrated processes. Journal of Nursing Education, 32(9), 406-414.

Lewis, J. B. (1992). The AIDS care dilemma: An exercise in critical thinking. The Journal of Nursing Education, 31(3), 136-137.

Miller, M.A., Malcolm, N.S. (1990). Critical thinking in the nursing curriculum. Nursing and Health Care, 11(2), 67-73.

National League for Nursing, (1989). Curriculum revolution: Reconceptualizing nursing education. New York: National League for Nursing Press.

National League for Nursing, (1991). National League for Nursing Accreditation Criteria: 1991. New York: National League for Nursing Press.

National League for Nursing, (1992). Perspective in Nursing-1991-1993. New York: National League for Nursing Press.

U. S. Department of Education (1988). Secretary's procedures and criteria for recognition of accrediting agencies. Federal Register, 53(127),25088-25099.

U.S. Department of Health and Human Services Public Health Service. (1992). Healthy people 2000 national health promotion and disease prevention objectives. Boston:Jones and Bartlett Publishers. 